\author{
VLADIMÍR ŠIMANSKÝ ${ }^{1 *}$, JERZY JONCZAK ${ }^{2}$, PETER KOVÁČIK ${ }^{3}$, DANIEL BAJČAN ${ }^{4}$ \\ ${ }^{1}$ Slovak University of Agriculture, Faculty of Agrobiology and Food Resources, Department of Soil Science \\ Tr. A. Hlinku 2, 94976 Nitra, Slovakia \\ ${ }^{2}$ Warsaw University of Life Sciences, Department of Soil Environment Sciences \\ Nowoursynowska Str. 159, 02-776 Warsaw, Poland \\ ${ }^{3}$ Slovak University of Agriculture, Faculty of Agrobiology and Food Resources, Department of Agrochemistry and Plant Nutrition \\ Tr. A. Hlinku 2, 94976 Nitra, Slovakia \\ ${ }^{4}$ Slovak University of Agriculture, Faculty of Biotechnology and Food Science, Department of Chemistry \\ Tr. A. Hlinku 2, 94976 Nitra, Slovakia
}

\title{
Impact of crop residues and biopreparations on nitrogen changes in Haplic Luvisol - model experiment
}

\begin{abstract}
Agroecosystem crop residues are considered to be a primary resource of organic substances, and are subject to the different transformation processes in the soil environment. The decomposition processes of organic substance can be also regulated by the application of the different biopreparations. The decomposition of organic substances in soil also causes changes in nitrogen content and its forms. It is essential for farmers to know about these processes in order flexibly to regulate and affect the transformation processes of the applied crop residues via the biopreparations directly in the production conditions. The changes of content and forms of nitrogen and its calculated parameters in Haplic Luvisol influenced by the applied crop residues (wheat - WR, rape - RR) and biopreparations (Betaliq, Trichomil) were monitored in the small-pot experiment carried out at the Department of Soil Science (FAFR, SUA-Nitra). The laboratory experiments were established for the incubation period 4, 7, 14, 28, 60, 90 and 180 days. The applied crop residues had statistically significant impact on the contents of total nitrogen $\left(\mathrm{N}_{t}\right)$ and potentially mineralizable nitrogen $\left(\mathrm{N}_{\mathrm{pot}}\right)$ and inorganic forms $\mathrm{N}$, similarly also the values of labile nitrogen $\left(\mathrm{L}_{\mathrm{N}}\right)$ and nitrogen pool index (NPI). The biopreparations affected statistically significantly the average values $\mathrm{N}_{\text {pot }}, \mathrm{L}_{\mathrm{N}}$, nitrogen lability index (NLI) and nitrogen management index (NMI). During the incubation period, the contents $\mathrm{N}_{\text {pot }}$ and values $\mathrm{L}_{\mathrm{N}}$ and other calculated indexes of nitrogen fluctuated significantly.
\end{abstract}

Keywords: Betaliq, Trichomil, Luvisol, Crop residues of wheat and rape oil

\section{INTRODUCTION}

In Slovakia the Luvisols represent some of the most utilised soils in the agricultural production. Their area is 265.4 thousand ha, which is $10.8 \%$ of the agricultural soil found in the Slovak Republic (SR). If the correct principles of cultivation and fertilization are followed, these soils become a good production type, suitable for growing common agricultural crops. In comparison with Chernozems and Mollic Fluvisols (the most productive soils in SR), they are more shallow, have a lower content of humus of worse quality, acid even slightly acid soil reaction and a higher content of clay under the A-horizon (Bielek 2017). This soil type requires increased care in order to improve or preserve its positive qualities. One of the most substantial factors, which can eliminate the negative impact of anthropogenic soil degradation, is sufficiency of the quality organic substances. In the course of the last two decades, Slovakia has been confronted with the serious problems, predominantly as a result of the radical decrease of animal production leading to the insufficient production of the high quality organic fertilizers, thus there is an imbalance of organic substance in agricultural soils (Green Report 2014). According to the latest information (Kobza et al. 2017) published in "Partial monitoring system - Soil" after the previous decrease the content of the soil organic substance and humus - mainly on the arable soil - has recently stabilized and even increased slightly (mainly in Fluvisols, Mollic Fluvisols, Chernozems, Podzols, and Leptosols) compared with the beginning of the soil monitoring in Slovakia as a result of the dramatic drop in the production of organic fertilizers. In the following monitoring period, the next possible growth of the organic substance could be associated with the subsidy policy of the SR Government in order to increase the organic substance in soil. Taking into consideration the quantity, the biggest primary source of the organic substance are after-harvest and root residues of the grown crops in the agroecosystems (Váchalová et al. 2016). The level of impact of crop residues on the formation of soil fertility depends not only on their 
quantity but also chemical composition. The application of crop residues into soil leads to the increase of carbon (Šimanský et al. 2008) and nitrogen content (Galantini and Rosell 2006), however, the other soil characteristics can also change. The regular supply of the organic substances into soil results in the increased quality of soils (Šimanský et al. 2008). In the future, the regulation processes of transformation of organic intakes into soils will intensively use different adjuvants, substrates, additives, mineral fertilizers or biopreparations, which enhance the positive humification processes in soils (Zaujec and Šimanský 2006). The biopreparations are organo-mineral substances that stimulate the different physiological processes and improve the ecological soil environment via some natural components or microorganisms, and also supply plants with macroand micronutrients (Basak 2008). Biopreparations through improved microbial activity support the decay of crop residues (Šimanský et al. 2006a, 2006b; Šimanský and Szombathová 2011), at the same time they have also the positive impact on the yield of the cultivated crops (Černý et al. 2018), via the improvement of nutrient intake from soil (Pačuta et al. 2017).

The soil environment is different in terms of its chemical, physical or biological parameters. It is apparent that the effect of crop residues and biopreparations will be different in the different soil types. Based on this, we assumed that (i.) as crop residues and biopreparations have the different composition, their effect would be different, (ii.) the biopreparations would stimulate the decay of crop residues, which would be reflected in the changes of individual forms of nitrogen in soil, and (iii.) the calculated nitrogen indexes (according to the calculated carbon indexes - Blair et al. 1995) would react more sensitively to the applied crop residues or the tested biopreparations in Luvisol than the determinated total nitrogen via their stronger differences between the individual monitored periods.

The objective of this study was to acquire information about the mutual relationship: crop residues - biopreparations - soil, where we emphasized predominantly the impact of crop residues and biopreparations on the changes of nitrogen and its forms as one of the most significant indicators of soil quality. The innovation of this study is the appraisal of changes of calculated nitrogen indexes after the application of crop residues or biopreparations.

\section{MATERIALS AND METHODS}

The soil for establishing the incubation experiment was taken from plough layer of Haplic Luvisol (HL) from the locality Golianovo (Slovakia). Before this experiment, the soil had slightly acid active soil reaction $(6.47 \mathrm{pH})$, low content of organic carbon $(1.08 \%)$, very strong hydrolytic acidity $\left(23 \mathrm{mmol} \mathrm{kg}{ }^{-1}\right)$, lower average cation exchange capacity $\left(189.4 \mathrm{mmol} \mathrm{kg}^{-1}\right)$ and saturated sorption complex $(87.8 \%)$. The soil was supplied by the after-harvest wheat residues (WR) in ratio straw : roots $=2: 1$; the element composition: $\mathrm{C}$ $=450 \mathrm{~g} \mathrm{~kg}^{-1} ; \mathrm{N}=9 \mathrm{~g} \mathrm{~kg}^{-1} ; \mathrm{C}: \mathrm{N}=50$ and rape $(\mathrm{RR})$ in ratio straw:roots $=1: 1$; the element composition: $\mathrm{C}=440 \mathrm{~g} \mathrm{~kg}^{-1} ; \mathrm{N}=11 \mathrm{~g} \mathrm{~kg}^{-1} ; \mathrm{C}: \mathrm{N}=40$. In the experiment, the following biopreparations were tested Betaliq (Redam, Ltd., Smržice, CzR) and Trichomil (product of Bioma, Ltd. Trnava, SR). More information about biopreparations (composition, properties) was published by Zaujec and Šimanský (2006).

The following treatments of the experiment were established:

HL - control (Haplic Luvisol)

HL +WR - Luvisol + wheat residues

$\mathrm{HL}+\mathrm{WR}+\mathrm{B}-$ Luvisol + wheat residues + Betaliq

$\mathrm{HL}+\mathrm{WR}+\mathrm{T}-$ Luvisol + wheat residues + Trichomil

$\mathrm{HL}+\mathrm{RR}$ - Luvisol + rape residues

$\mathrm{HL}+\mathrm{RR}+\mathrm{B}-$ Luvisol + rape residues + Betaliq

$\mathrm{HL}+\mathrm{RR}+\mathrm{T}$ Luvisol + rape residues + Trichomil

The laboratory experiments were carried out in the pots of the volume $0.22 \mathrm{dm}^{3} .200 \mathrm{~g}$ of soil and $4 \mathrm{~g}$ of crop residues were weighed and put into the prepared pots with the sieve and filter paper at the bottom (three replications) with the duration of 4,7 , $14,28,60,90$ and 180 days. In order to adapt the ratio $\mathrm{C}: \mathrm{N}$ in the treatments with crop residues, $\mathrm{N}$ was applied, equal the usage in practice, i. e. $1 \mathrm{~kg} \mathrm{~N}$ per $100 \mathrm{~kg}$ of crop residues, in the form of $\left(\mathrm{NH}_{4}\right)_{2} \mathrm{SO}_{4}$ and $1 \%$ of their solution was used in the treatments with biopreparations ( $10 \mathrm{ml}$ for Betaliq and $12 \mathrm{ml}$ for Trichomil). The experiment was located in the incubation room, where optimal conditions were maintained (temperature $23-25^{\circ} \mathrm{C}$, humidity $50-60 \%$ FWC) for the decay of organic substances. After the completion of incubation the individual soil samples of the established treatments were analyzed. The individual contents and forms of nitrogen were detected: content of total nitrogen - by Kjeldahl method (Peterburskij 1963), content of potentially mineralizable nitrogen $\left(\mathrm{N}_{\text {pot }}\right)$ (Standford and Smith 1978), content of ammonium nitrogen $\left(\mathrm{NH}_{4}{ }^{+}\right)-$ colorimetrically with Nessler's reagent in extract $1 \%$ $\mathrm{K}_{2} \mathrm{SO}_{4}$ and content of nitrate nitrogen $\left(\mathrm{NO}_{3}{ }^{-}\right)-$colorimetrically with phenol disulphonic acid in extract $1 \% \mathrm{~K}_{2} \mathrm{SO}_{4}\left(\mathrm{NH}_{4}^{+}+\mathrm{NO}_{3}^{-}=\mathrm{N}_{\mathrm{an}}\right)$. The following indexes for nitrogen were also calculated (equations $1-5)$ : 
Calculation of nitrogen lability $\left(\mathrm{L}_{\mathrm{N}}\right)$

$\mathrm{N}_{\mathrm{NL}}=\mathrm{N}_{\mathrm{t}}-\mathrm{N}_{\text {pot }}$

$\mathrm{L}_{\mathrm{N}}=\mathrm{N}_{\text {pot }} / \mathrm{N}_{\mathrm{NL}}$

where:

$\mathrm{N}_{\text {pot }}$ - potentially mineralizable nitrogen, $\mathrm{N}_{\mathrm{NL}}-$ nonlabile nitrogen, $\mathrm{N}_{\mathrm{t}}-$ total nitrogen content.

Calculation of nitrogen lability index (NLI)

$\mathrm{NLI}=\mathrm{L}_{\mathrm{NCR}} / \mathrm{L}_{\mathrm{NCo}} \times 100$

where:

$\mathrm{L}_{\mathrm{N} \mathrm{CR}}$ - nitrogen lability treatment with crop residues,

$\mathrm{L}_{\mathrm{N} \text {. Co }}$ - lability of control treatment without crop residues.

Calculation of nitrogen pool index (NPI)

$\mathrm{NPI}=\mathrm{N}_{\mathrm{tCR}} / \mathrm{N}_{\mathrm{tCo}}$

where:

$\mathrm{N}_{\mathrm{tCR}}-\mathrm{N}_{\mathrm{t}}$ treatment with crop residues, $\mathrm{N}_{\mathrm{t} \text { Co }}-\mathrm{N}_{\mathrm{t}}$ control treatment without crop residues.

Calculation of nitrogen management index (NMI) $\mathrm{NMI}=\mathrm{NPI} \times \mathrm{NLI}$

The individual forms of nitrogen were evaluated in the program Statgraphics Centurion XV. I (Statpoint Technologies, Inc., USA) by multidimensional scatter analysis (ANOVA). The differences between the variants were further evaluated by LSD test with the minimal significance level $P<0.05$. The dynamics of changes of the particular nitrogen forms were assessed via the simple linear analysis.

\section{RESULTS AND DISCUSSION}

After the completion of the incubation experiment, we detected that the applied crop residues significantly increased the values of total nitrogen $\left(\mathrm{N}_{t}\right)$ in soil. On the whole, the average values $\mathrm{N}_{t}$ were increased by $49 \%$ and $59 \%$ in variants RR and WR, or compared with the control (Table 1). The crop residues are considered to be the essential source of the organic substance (Naresh et al. 2017), therefore their application into soil is associated with the increased content $\mathrm{C}$ and also $\mathrm{N}$ in soils (Christensen et al. 1994). The changes after application of the crop residues into soil correspond with the chemical composition (Zaujec and Šimanský 2006) of the crop residues themselves. The tested biopreparations did not change the average values $\mathrm{N}_{t}$ significantly. On average, in all treatments the average values $\mathrm{N}_{\mathrm{t}}$ were decreased statistically significantly by $143 \mathrm{mg} \mathrm{kg}^{-1}$ along with the period of incubation, which shows the occurring transformation processes in soil (Zaujec and
Šimanský 2006). Of course, the dynamics of changes of values $\mathrm{N}_{t}$ during the whole incubation period was different (Figure 1A) and depended on the applied crop residues and the tested biopreparations. The values $\mathrm{N}_{\mathrm{t}}$ in the control were not changed significantly, which proves the fact that $\mathrm{N}_{t}$ in soil is a relatively stable parameter, as its highest proportion is the organic $\mathrm{N}$ and only a low proportion of it is liable to a transformation (Ondrišík 2013, Kováčik 2014). All treatments either with the applied crop residues or biopreparations registered the drop $\mathrm{N}_{\mathrm{t}}$ in the course of the incubation period. However, a significant (linear) decrease was recorded only in the cases of the applied wheat residues and the tested biopreparation Betaliq. In the treatments, where wheat residues were applied, the values $\mathrm{N}_{t}$ significantly decreased linearly at the rate $51.8 \mathrm{mg} \mathrm{N}$ per $1 \mathrm{~kg}$ of soil in 180 days during the monitored incubation period, which meant the drop by $10 \% \mathrm{~N}_{\mathrm{t}}$ in soil. On average, the treatments with the tested Betaliq (B) proved the statistically evidential linear trend of decrease of content $\mathrm{N}_{\mathrm{t}}$, during the monitored incubation period because in this treatment the rate of drop $\mathrm{N}_{\mathrm{t}}$ in soil was $47.8 \mathrm{mg} \mathrm{N}$ per $1 \mathrm{~kg}$ of soil in 180 days, which also mean the decrease by $10 \% \mathrm{~N}_{\mathrm{t}}$ in soil (Table 3). The content of potentially mineralizable nitrogen $\left(\mathrm{N}_{\text {pot }}\right)$ can be dependent significantly on the quantity of the total N in soil (Doran 1987, Maková 2015), which was not approved completely by our results, as the negative, however, statistically insignificant correlation between $\mathrm{N}_{t}$ and $\mathrm{N}_{\text {pot }}$ was detected $(\mathrm{r}=-0.142, P>0.05)$. The content $\mathrm{N}_{\text {pot }}^{\text {pot }}$ in soil can be influenced by the soil management with the equal reserves of the total N (Doran 1987), which is associated with the content of hydrolyzable $\mathrm{N}$, which represents $52-84 \%$ out of $\mathrm{N}_{t}$ (Kováčik 2014, Bielek 2017). As the crop residues of the different chemical composition were applied into soil and two different biopreparations were tested, our assumptions were approved. On the whole, after the completion of the incubation experiment the average values $\mathrm{N}_{\text {pot }}$ changed significantly as a result of the application of the crop residues and also the application of Trichomil (Table 1 ). The average values $\mathrm{N}_{\text {pot }}$ were lower by 32 and $36 \mathrm{mg} \cdot \mathrm{kg}^{-1}$ in the treatments WR and RR or compared with the control (HL). This fact shows that, on the one hand, the applied crop residues were subject to the transformation processes, on the other hand, their mineralization was eliminated significantly in comparison with the HL treatment. This information corresponds with the founding of Cayuela et al. (2009), who claimed that the applied crop residues in soil cause the immediate immobilization $\mathrm{N}$, which eliminates the microbial growth, enzymatic synthesis 
TABLE 1. Effect of crop residues and biopreparates on total $\mathrm{N}$ and its forms content in soil

\begin{tabular}{|c|c|c|c|c|c|c|c|}
\hline \multicolumn{3}{|l|}{ Factor } & \multirow{2}{*}{\multicolumn{2}{|c|}{$\frac{\mathrm{N}_{\mathrm{t}}}{\left(\mathrm{mg} \mathrm{kg}^{-1}\right)} \mathrm{N}_{\text {pot }}$}} & $\mathrm{N}_{\text {an }}$ & $\mathrm{NH}_{4}^{+}$ & $\mathrm{NO}_{3}^{-}$ \\
\hline \multirow{6}{*}{ Crop residues } & & & & & & & \\
\hline & P-Value & & 0.0000 & 0.0148 & 0.0000 & 0.0000 & 0.0000 \\
\hline & & 0 & 1432 & 108 & 37 & 26 & 11 \\
\hline & & Wheat & 2269 & 76 & 734 & 633 & 93 \\
\hline & & Rape & 2132 & 72 & 502 & 378 & 121 \\
\hline & \pm limits & & 117 & 24 & 93 & 99 & 42 \\
\hline \multirow[t]{5}{*}{ Biopreparates } & P-Value & & 0.3001 & 0.0769 & 0.5373 & 0.3443 & 0.5692 \\
\hline & & 0 & 1956 & 75 & 440 & 367 & 73 \\
\hline & & Betaliq & 1972 & 83 & 406 & 315 & 86 \\
\hline & & Trichomil & 1904 & 97 & 405 & 323 & 70 \\
\hline & \pm limits & & 91 & 19 & 72 & 77 & 33 \\
\hline
\end{tabular}
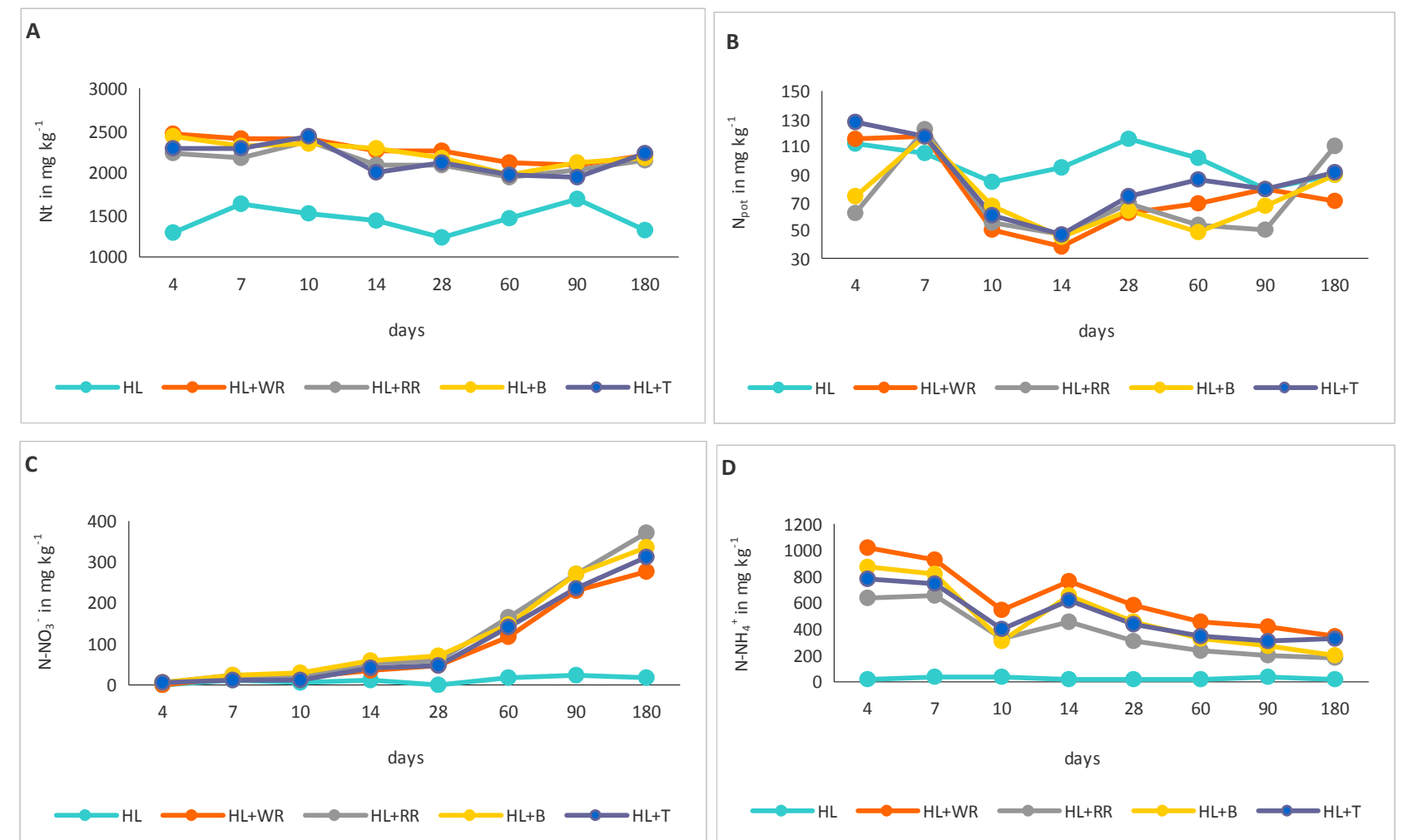

FIGURE 1. Changes of A - total nitrogen, $\mathrm{B}$ - potentially mineralizable nitrogen, $\mathrm{C}$ - nitrate nitrogen, and D - ammonium nitrogen in soil during 180 days of incubation

Treatments are mentioned in „Materials and Methods” section.

and the following mineralization. The next reason can be the application $\mathrm{N}$ in the form of ammonium sulphate, which corrects the ratio $\mathrm{C}: \mathrm{N}$ for the acceleration and starting the decomposition processes of the afterharvest residues. The ratio $\mathrm{C}: \mathrm{N}$ of the crop residues has a significant impact on the rate of the decomposition processes and mineralization (Gough et al. 2009). However, the microorganisms preferred markedly the supplied $\mathrm{N}$ in the form of ammonium sulphate. It is necessary to emphasize that these values $\left(\mathrm{N}_{\text {pot }}\right)$ represented $8 \%, 3.3 \%$ and $3.4 \%$ of $\mathrm{N}_{\mathrm{t}}$ in $\mathrm{HL}$,
WR and RR treatments. Out of the biopreparations only the tested Trichomil (Table 1) increased the average values $\mathrm{N}_{\text {pot }}$ after the completion of incubation. During the monitored incubation period, when evaluating the dynamics of changes of values $\mathrm{N}_{\text {pot }}$, we did not detected either a significant falling or rising trend (Table 3, Figure 1B), which refers to a considerable sensitivity of this parameter as a result of the different soil management. In spite of the fact that the inorganic nitrogen $\left(\mathrm{N}_{\mathrm{an}}\right)$ represents only a small proportion in soil out of the total nitro- 
gen about 1-2\% (Vaněk et al. 2013), it has a substantial impact from the aspect of plants nutrition. However, the fundamental fact is that even this low quantity is liable to the considerable seasonal changes (Ondrišík et al. 2009, Ondrišík 2013), which are influenced apart from the climatic facts (Malhi et al. 2006) also by the soil management including soil fertilization (Vaněk et al. 2013). On the whole, the average values $\mathrm{N}_{\text {an }}$ were increased significantly as a result of the application of the crop residues, at the same time it was reflected in the total increase $\mathrm{N}_{\mathrm{an}}$ after the application of residues WR like $\mathrm{RR}$. The biopreparations decreased overall the values $\mathrm{N}_{\mathrm{an}}$, but the differences between the variants were not significant (Table 1). During the whole incubation period the dynamics of changes registered the gradual drop in the values $\mathrm{N}_{\text {an }}$, however, a significant linear decrease of values $\mathrm{N}_{\text {an }}$ was recorded only in the WR treatment. The average decline of the values $\mathrm{N}_{\text {an }}$ in this variant was $55 \mathrm{mg} \cdot \mathrm{kg}^{-1}$ in 180 days, which means the drop 39\% in comparison with the initial phase (the difference between the 4th day and 180th day of incubation). The total average content $\mathrm{N}^{-} \mathrm{NH}_{4}{ }^{+}$ increased significantly 25 and 15-times as much as a result of the application of after-harvest residues WR and RR, or compared with the control (HL). After the application of crop residues the average contents $\mathrm{N}-\mathrm{NO}_{3}{ }^{-}$increased, in particular for the residues WR 8-times and for the residues RR 11-times in comparison with the control (Table 1). As we adjusted $\mathrm{C}: \mathrm{N}$ by ammonium sulphate in all variants, we assumed that it would be reflected in the dynamics of changes of these inorganic forms $\mathrm{N}$, by intensification of nitrification processes. $\mathrm{N}-\mathrm{NH}_{4}{ }^{+}$ decreased more intensively in case of the crop residues WR than RR, on the other hand, $\mathrm{N}^{-\mathrm{NO}_{3}}{ }^{-}$increased more intensively in case of RR than WR (Table $3)$. This process can be inhibited by using inhibitors of nitrification (Zaman and Blennerhasset 2010, Slamka and Ložek 2017). As the biopreparations are the soil additives that regulate the transformation processes of the
TABLE 3. Relationship between content of total $\mathrm{N}$ and its forms in soil and time of soil incubation ( $\mathrm{y}=\mathrm{N}$ and its forms; $\mathrm{x}=$ time of incubation)

\begin{tabular}{|c|c|c|c|c|}
\hline \multirow[t]{2}{*}{ Treatment } & \multicolumn{2}{|l|}{$\mathrm{N}_{\mathrm{t}}$} & \multicolumn{2}{|l|}{$N_{\text {pot }}$} \\
\hline & Linear equation & $\mathrm{R}^{2}$ & Linear equation & $\mathrm{R}^{2}$ \\
\hline $\mathrm{HL}$ & $y=0.82 x+1440$ & 0.0001 & $y=-2.55 x+110$ & 0.2375 \\
\hline $\mathrm{HL}+\mathrm{WR}$ & $y=-51.8 x+2502$ & 0.7889 & $y=-4.85 x+97.1$ & 0.1768 \\
\hline $\mathrm{HL}+\mathrm{RR}$ & $y=-29.8 x+2266$ & 0.3120 & $y=-0.18 x+72.4$ & 0.0002 \\
\hline $\mathrm{HL}+\mathrm{B}$ & $y=-47.8 x+2444$ & 0.8085 & $y=-2.17 x+81.8$ & 0.0532 \\
\hline \multirow[t]{2}{*}{$\mathrm{HL}+\mathrm{T}$} & $y=-40.8 x+2344$ & 0.3257 & $y=-3.96 x+103$ & 0.1343 \\
\hline & $\mathrm{NH}_{4}^{+}$ & & $\mathrm{NO}_{3}^{-}$ & \\
\hline $\mathrm{HL}$ & $y=-0.81 x+29.3$ & 0.0438 & $\mathrm{y}=2.33 \mathrm{x}+0.81$ & 0.5860 \\
\hline HL+WR & $y=-91.9 x+1047$ & 0.8334 & $\mathrm{y}=39.1 \mathrm{x}-82.7$ & 0.8345 \\
\hline HL+RR & $y=-68.9 x+688$ & 0.8431 & $y=50.6 x-107$ & 0.8339 \\
\hline $\mathrm{HL}+\mathrm{B}$ & $y=-90.5 x+893$ & 0.7305 & $\mathrm{y}=46.9 \mathrm{x}-94.0$ & 0.8536 \\
\hline $\mathrm{HL}+\mathrm{T}$ & $y=-67.8 x+799$ & 0.7718 & $y=43.4 x-94.4$ & 0.8314 \\
\hline
\end{tabular}



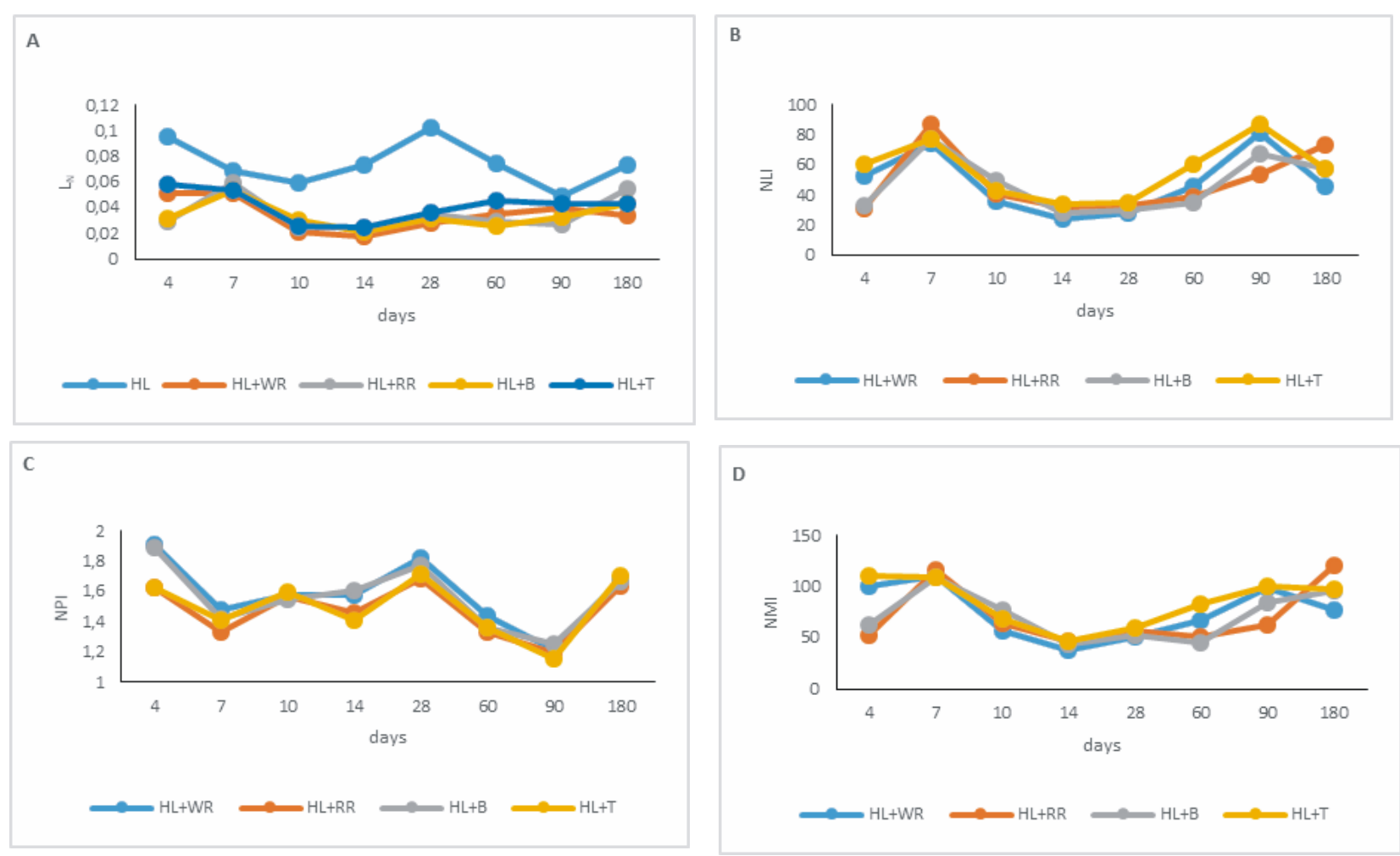

FIGURE 2. Changes of A - nitrogen lability, B - nitrogen lability index, C - nitrogen pool index, and D - nitrogen management index during 180 days of incubation

Treatments are mentioned in „Materials and methods” section.

be more sensitive indicators of the soil organic substance. The average higher values $\mathrm{L}_{\mathrm{N}}$ were significantly influenced by the applied crop residues and also by biopreparations (Table 2). On the whole, the average values $\mathrm{L}_{\mathrm{N}}$ in the treatments with crop residues were lower than in the control (HL), on the other hand, they were higher in the treatments with biopreparations. The stated average values proved a higher resistance of the applied crop residues to the decomposition by microorganisms, i.e. that the organic substance in the treatments of the crop residues were not subject to significant change. The change of the crop residues in soil was qualified by the addition of biopreparations. The apparent change of the crop residues and consequently also the degradation of organic substance by microbial activity was detected predominantly with Trichomil (statistically significantly increase of values $\mathrm{L}_{\mathrm{N}}$ ). During the monitored incubation 180-day period, the dynamics of changes of values $\mathrm{L}_{\mathrm{N}}$ fluctuated considerably, therefore it was not possible to identify any positive or negative trend (Table 4$)$. The values $L_{N}$ positively correlated significantly with the values NLI $(\mathrm{r}=0.887, P<0.001)$. The difference of the average values NLI between the variants with the crop residues was not significant, however, on the whole a significant difference was detected as a result of the application of biopre- parations (Table 2). The values NLI were increased by $12 \%$ and $36 \%$ in the treatment $\mathrm{B}$ and $\mathrm{T}$, or in comparison with the control (but it was statistically significant only with Trichomil). The stated information proves again the stimulative effect of biopreparations on the intensification of the transformation processes by the microbial activity (Šimanský et al. 2006a, 2006b). During the incubation the dynamics of changes in the values NLI fluctuated considerably, similarly to $\mathrm{L}_{\mathrm{N}}$ therefore it was not possible to identify any significant linear trend of their decrease or increase (Table 4). In the course of the monitored period, we identified two significant peaks of values NLI in all variants (apart from RR) after 7 and 90 days of incubation (Figure 2B). The application of the organic substance either in the form of organic fertilizers or crop residues results in the gradual increase of lability of organic substance (Shen et al. 2001, Šimanský and Tobiašová 2010) until the depletion of easily available (more labile) organic substances, which are liable to the rapid changes. Based on the average values NPI, it is clear that more intensive degradation of soil organic substance was detected in the treatments RR than WR. This fact refers to the composition of the crop residues because the after-harvest residues RR contain more easily degradable organic substances than the residues of wheat 
(Zaujec and Šimanský 2006). The tested biopreparations had a significant impacton the average values NPI as well (Table2). More intensive microbial degradation was detected in the treatments with Trichomil, which corresponds with the other monitored parameters as $\mathrm{L}_{\mathrm{N}}$, NLI. The dynamics of changes fluctuated quite considerably and without any significant linear trend of decrease or increase during the monitored incubation period (Figure 2C). The effect of applied crop residues and added biopreparations was evaluated also by

TABLE 4. Relationship between values of $\mathrm{N}$ indexes and time of soil incubation $(\mathrm{y}=\mathrm{N}$ indexes; $\mathrm{x}=$ time of incubation)

\begin{tabular}{lllll}
\hline Treatment & $\mathrm{L}_{\mathrm{N}}$ & \multicolumn{3}{l}{ NLI } \\
\cline { 2 - 5 } & Linear equation & $\mathrm{R}^{2}$ & Linear equation & $\mathrm{R}^{2}$ \\
\hline $\mathrm{HL}$ & $\mathrm{y}=-0.002 \mathrm{x}+0.08$ & 0.0789 & - & - \\
\hline $\mathrm{HL}+\mathrm{WR}$ & $\mathrm{y}=-0.0014 \mathrm{x}+0.04$ & 0.0788 & $\mathrm{y}=0.12 \mathrm{x}+47.4$ & 0.0006 \\
\hline $\mathrm{HL}+\mathrm{RR}$ & $\mathrm{y}=0.0005 \mathrm{x}+0.03$ & 0.0079 & $\mathrm{y}=1.535 \mathrm{x}+41.9$ & 0.0318 \\
\hline $\mathrm{HL}+\mathrm{B}$ & $\mathrm{y}=-0.0004 \mathrm{x}+0.04$ & 0.0072 & $\mathrm{y}=0.916 \mathrm{x}+43.1$ & 0.0141 \\
\hline $\mathrm{HL}+\mathrm{T}$ & $\mathrm{y}=-0.0011 \mathrm{x}+0.05$ & 0.0510 & $\mathrm{y}=0.911 \mathrm{x}+52.7$ & 0.0135 \\
\hline & $\mathrm{NPI}$ & & $\mathrm{NMI}$ & \\
\hline HL & - & - & - & - \\
\hline $\mathrm{HL}+\mathrm{WR}$ & $\mathrm{y}=-0.036 \mathrm{x}+1.75$ & 0.1611 & $\mathrm{y}=-2.05 \mathrm{x}+83.9$ & 0.0363 \\
\hline $\mathrm{HL}+\mathrm{RR}$ & $\mathrm{y}=-0.013 \mathrm{x}+1.54$ & 0.0304 & $\mathrm{y}=2.10 \mathrm{x}+61.9$ & 0.0305 \\
\hline $\mathrm{HL}+\mathrm{B}$ & $\mathrm{y}=-0.033 \mathrm{x}+1.72$ & 0.1444 & $\mathrm{y}=0.31 \mathrm{x}+70.3$ & 0.0010 \\
\hline HL+T & $\mathrm{y}=-0.013 \mathrm{x}+1.56$ & 0.0266 & $\mathrm{y}=-1.01 \mathrm{x}+89.4$ & 0.0109 \\
\hline
\end{tabular}

the calculated values NMI. Lo-

wer values NMI indicate more intensive changes of content of organic substance as a result of the soil management and a higher quantity of nitrogen released from soil. The after-harvest residues did not have any significant effect on the average values NMI. The biopreparation Trichomil had more than Betaliq on higher quantity $\mathrm{N}$ released into soil than control (Table 2). Similarly to other calculated parameters $\left(\mathrm{L}_{\mathrm{N}}, \mathrm{NLI}\right.$ and NPI), the dynamics of NMI of these values also fluctuated considerably and without the statistically significant linear trend of increase or decrease (Table 4).

\section{CONCLUSIONS}

On the whole, after the completion of the incubation experiment, the crop wheat residues in Luvisol increased significantly in terms of total nitrogen, inorganic nitrogen, ammonium nitrogen and the values of nitrogen management index, on the other hand, they decreased considerably as regards nitrogen lability. The rape residues increased significantly in terms of potentially mineralizable nitrogen after the completion of the experiment, and their application into Luvisol had the statistically significant impact on the increase of nitrate nitrogen. The acquired results approved the significant effect of the tested biopreparations on the individual forms of nitrogen in Luvisol. The biopreparation Trichomil increased significantly the average values of the potentially mineralizable nitrogen and nitrogen lability and management indices. However, after the completion of the experiment it decreased significantly as regards the nitrogen pool index.

From the aspect of the dynamics of contents, considerable differences were detected in changes of individual forms of nitrogen depending on the applied crop residues and the applied biopreparations. The contents of the potentially mineralizable nitrogen and values of nitrogen lability indexes, but also other calculated nitrogen indexes, registered considerable fluctuation during the incubation period, and it was not possible to identify any positive or negative trend. The stated facts show and approve our assumption that these parameters are characterized by higher sensitivity to changes in soil management.

\section{ACKNOWLEDGMENTS}

This study was supported by the Scientific Grant Agency (VEGA) - project No. 1/0136/17.

\section{REFERENCES}

Basak A., 2008. Klasyfikacja biostymulatorów na podstawie opinii badaczy oraz firm chemicznych krajowych i zagranicznych (Classification of biostimulators based on the opinions of researchers and domestic and foreign chemical companies). Wieś Jutra 5: 31-34.

Bielek P., 2017. Pôdoznalectvo pre environmanažérov (Soil science for environmental managers). SAU, Nitra: 318 p.

Blair G.J., Lefroy R.D.B., Lisle L., 1995. Soil carbon fractions based on their degree of oxidation, and the development of a carbon management index for agricultural system. Australian Journal of Agricultural Research 46: 1459-1466.

Cayuela M.L., Sinicco T., Mondini C., 2009. Mineralization dynamics and biochemical properties during initial decomposition of plant and animal residues in soil. Applied. Soil Ecology 41: 118-127.

Černý I., Pačuta V., Ernst D., Gažo J., 2018. Tvorba úrody a cukornatosti repy cukrovej v závislosti od ročníka a foliárnej aplikácie biologicky aktívnych látok a hnojív (Formation of sugar beet yield and sugar content depending on year and foliar application of biologically active substances and fertilizers). LCaŘ 134(4): 141-154. 
Christensen N.B., Lindemann W.C., Sosa E.S., Gill L.R., 1994. Nitrogen and carbon dynamics in no-till and stubble mulch tillage systems. Agronomy Journal 86: 298-303.

Conteh A., Blair G.J., Lefroy, R.D.B., Whitbread A., 1999. Labile organic carbon determined by permangante oxidation and its relationships to other measurements of soil organic carbon. Humic Substances in the Environment 1: 3-15.

Doran J.W., 1987. Microbial biomass and minerazible nitrogen distributions in no-tillage and plowed soils. Biology and Fertility of Soils 5(1): 68-75.

Galantini J., Rosell R., 2006. Long-term fertilization effects on soil organic matter quality and dynamics under different production systems in semiarid Pampean soils. Soil \& Tillage Research 87: 72-79.

Gough C.M., Flower C.E., Vogel C.S., Dragoni D., Curtis P.S., 2009. Whole-ecosystem labile carbon production in a north temperate deciduous forest. Agricultural and Forest Meteorology 149: 1531-1540.

Green Report, 2014. Green Report for 2013. Národné pol'nohospodárske a potravinárke centrum NPPC, Bratislava: $65 \mathrm{p}$.

Kobza J., Barančíková G., Makovníková J., Pálka B., Styk J., Širáň M., 2017. Current state and development of land degradation processes based on soil monitoring in Slovakia. Agriculture (Pol'nohospodárstvo) 63(2): 74-85.

Kováčik P., 2014. Princípy a spôsoby výživy rastlín (Principles and methods of plant nutrition). SPU, Nitra: $278 \mathrm{p}$.

Maková J., 2015. Vplyv hnojenia na vybrané biologické indikátory kvality a zdravia pôdy (Impact of fertilization on selected biological indicators of soil quality and health). SPU, Nitra: $120 \mathrm{p}$.

Malhi S.S., Lemke R.L., Wang Z., Farrell R., Chhabra B.S., 2006. Tillage, nitrogen and crop residue effects on crop yield and nutrient uptake, soil quality and greenhouse gas emissions. Soil \& Tillage Research 90(1-2): 171-183.

Naresh R.K., Panwar A.S., Dhaliwal S.S., Gupta R.K., Kumar A., Rathor R.S., Kumar A., Kumar D., Lal M., Kumar S., Tyagi S., Kumar V., Singh S.P., Singh V., Mahajan M.Ch., 2017. Effect of Organic Inputs on Strength and Stability of Soil Aggregates Associated Organic Carbon Concentration under Rice-Wheat Rotation in Indo-Gangetic Plain Zone of India. International Journal of Current Microbiology and Applied Sciences 6(10): 1973-2008.

Ondrišík P., 2013. Dynamika anorganického dusíka v pôde a možnosti jeho regulácie (Dynamics of inorganic nitrogen in soil and possibilities of its regulation). SPU, Nitra: $97 \mathrm{p}$.

Ondrišík P., Urminská J. Porhajášová J., Ňanšanská M., 2009. Vplyv agrotechnických zásahov na sezónne zmeny anorganického dusíka v pôde (Effect of agrotechnical interventions on seasonal changes of inorganic nitrogen in soil). Journal of Central European Agriculture 10(1): 101-107.

Pačuta V., Rašovský J., Černý I., 2017. Vplyv ročníka, odrody a biopreparátov Alga $300 \mathrm{P}, \mathrm{K}$ a Alga 600 na úrodové parametre repy cukrov (Influence of weather conditions, variety and biopreparations Alga $300 \mathrm{P}, \mathrm{K}$ and Alga 600 on molasses components, white sugar yield of sugar beet). LCaŘ, 133(7-8): 232-236.

Peterburskij A.V., 1963. Praktikum po agronomičeskoj chimiji (Practice in agronomic chemistry). Izd. Sel'skochozjajstvennoj literatury, $\bullet$ urnalov a plakatov, Moskva: $591 \mathrm{p}$.

Shen H., Xu Z.H., YAN X.L., 2001. Effect of fertilization on oxidizible carbon, microbial biomass carbon and mineralizable carbon under different agroecosystems. Communication in Soil Science and Plant Analalysis 32(2): 1575-1588.

Šimanský V., Polláková N., 2016. The effects of soil management practices on soil organic matter changes within a productive vineyard in the Nitra viticulture area (Slovakia). Agriculture (Pol'nohospodárstvo) 62(1): 1-9.

Šimanský V., Tobiašová E., 2010. Impact of tillage, fertilization and previous crop on chemical properties of Luvisol under barley farming system. Journal of Central European Agriculture 11(3): 245-254.

Šimanský V., Tobiašová E., Chlpík J., 2008. Soil tillage and fertilization of Orthic Luvisol and their influence on chemical properties, soil structure stability and carbon distribution in water-stable macro-aggregates. Soil \& Tillage Research, 100(1-2): 125-132.

Šimanský V., Zaujec A., Tobiašová E., 2006a. Vplyv biostimulátora Trichomil na transformačné procesy (Effect of Trichomil biostimulator on transformation processes). [In:] Biotechnology 2006 (Řehout V., Editors). Scientific Pedagogical Publishing, České Budějovice: 1050-1052.

Šimanský V., Zaujec A., Tobiašová E., 2006b. Vplyv biostimulátora Beta-Liq na transformačné procesy pozberových zvyškov pšenice letnej formy ozimnej a kapusty repkovej pravej (Effect of Beta-Liq biostimulator on the transformation processes of harvest residues of winter wheat and oil rape). [In:] Biotechnology 2006 (Řehout V., Editors). Scientific Pedagogical Publishing, České Budějovice: 1053-1055.

Šimasnký V., Szombathová N., 2011. Basal, potential and relative respiration with dependence on applied crop residues and bio-stimulators in Haplic Chernozems. Journal of Central European Agriculture 12(4): 702-715.

Slamka P., Ložek O., 2017. Comparison of slowly and quickly releasing fertilizers effect on the yield of green pepper and its distribution to the respective harvests. Agrochémia 2: 14-20.

Standford G., Smith S.J., 1978. Oxidative release of potentially mineralizable soil nitrogen by acid permanganate extraction. Soil Science 126(4): 210-218.

Szombathová N., 1999. The comparison of soil carbon susceptibility to oxidation by $\mathrm{KMnO}_{4}$ solutions in different farming systems. Humic substances in the environment 1: 35-39.

Váchalová R., Kolář L., Muchová Z., 2016. Primární organická půdní hmota a humus, dvě složky půdní organické hmoty. SPU, Nitra: $122 \mathrm{p}$.

Vaněk V., Ložek O., Balík J., Pavlíková D., Tlustoš P., 2013. Vý•iva pol'ných a záhradných plodín (Nutrition of field and garden crops). Profi Press, Nitra: 184 p.

Vieira F.C.B., Bayer C., Zanatta J.A., Dieckow J., Mielniczuk J., He Z.L., 2007. Carbon management index based on physical fractionation of soil organic matter in an Acrisol under longterm no-till cropping systems. Soil \& Tillage Research 96(1-2): 195-204.

Zaman M., Blennerhassett J.D., 2010. Effects of the different rates of urease and nitrification inhibitors on gaseous emissions of ammonia and nitrous oxide, nitrate leaching and pasture production from urine patches in an intensive grazed pasture system. Agriculture, Ecosystems \& Environment, 136(3-4): 236-246.

Zaujec A., Šimanský V., 2006. Vplyv biostimulátorov rozkladu rastlinných zvyškov na pôdnu štruktúru a organickú hmotu pôdy (Effect of biostimulators of the plant residues degradation on the soil structure and soil organic matter). SPU, Nitra: $112 \mathrm{p}$.

Received: August 30, 2018

Accepted: December 14, 2018

Associated editor: B. Rutkowska 